УДК 614.8.027:616-036.865-057.11

DOI: $10.15587 / 2313-8416.2015 .36746$

\title{
ПОПУЛЯЦЙНИЙ ЕКОНОМІЧНИЙ ЕФЕКТ ВІД ПОПЕРЕДЖЕННЯ НЕЩАСНИХ ВИПАДКІВ НА ВИРОБНИЦТВІ ТА ІНВАЛІДНОСТІ ПРАЦЮЮЧИХ
}

\author{
(C) О. М. Крекотень, О. Г. Кабаненко
}

Очіночним критерієм визначення попередженого економічного збитку став один випадок виробничої травми, при цььому не визначалась кількість утрачених років життя та якість життя постраждалого. Економічний ефект від попередження одного випадку виробничої травми склав 77888 грн. 05 коп., а від попередження одного випадку інвалідності внаслідок виробничої травми 98537 грн. 63 коп.

Ключові слова: економічна ефективність, витрати, виробнича травма

\begin{abstract}
Aim. To estimate the economic effect from prevention of accidents at production sites.
Materials and Methods. The methods for determination of the economic efficiency were based on calculation of the indirect economic effect determined by the value of the prevented economic loss due to reduction of direct and indirect expenses. The estimation criterion was represented by one case of an occupational injury at an industrial enterprise. The number of the lost years of life and the life quality of the injured was not estimated.

Results. Calculation of the economic effect from prevention of one occupational injury t made up 77888 UAH $05 \mathrm{kop}$. and from prevention of one case of disability caused by an occupational injury - 98537 UAH $63 \mathrm{kop}$.

Conclusions. The mentioned calculations with determination of the most financially unprofitable aspects proved the necessity to review and improve the national policy as to preservation and improvement of health of the working population according to all the components of its provision
\end{abstract}

Keywords: economic efficiency, expenses, occupational injury

\section{1. Вступ}

Ефективність охорони здоров'я може бути медичною, соціальною та економічною, що виражається різними показниками якості й ефективності діяльності медичних установ. Економічна ефективність - це оптимізація витрат на медичне обслуговування, економічне обгрунтування заходів 3 охорони здоров'я, економічний аналіз використання коштів у медичній галузі [1-4].

Економічна оцінка наслідків того чи іншого захворювання або стану будується на теорії «людського капіталу», розробленої G. Becker у 1964 p. і перенесеної в систему охорони здоров'я D. P. Rice в 1966 р. [4], особливість застосування якої полягає в тому, що оцінка проводиться на основі офіційних статистичних даних про конкретну хворобу (захворюваність, поширеність, смертність) i може бути представлена у грошовому еквіваленті. Поняття «економічні втрати» багатогранне й охоплює не лише витрати на лікування, реабілітацію, перекваліфікацію хворих та утримання інвалідів, а й втрати, що безпосередньо чи опосередковано зумовлені впливом виробничого середовища: погіршення якості та скорочення тривалості життя, погіршення показників здоров'я та працездатності, порушення репродуктивної функції населення, підвищення навантаження на систему охорони здоров'я, недоотриманням розміру ВВП [2].

\section{2. Постановка проблеми}

За даними Кундієва Ю. I [5], в Україні на виробництві щодня одержують травми 55-60 працівників, з них 3-4 - зі смертельними наслідками, що призводить окрім економічних збитків, до соціальних i психологічних утрат. Часткова або повна втрата робітником працездатності на обмежений відрізок часу (протягом декількох днів, місяців, років) або до кінця працездатного періоду залишаються невідновними втратами робочої сили. В економічному плані вони визначаються рівнем витрат на досягнення фактичної кваліфікації постраждалого, ступенем і тривалістю втрати працездатності. При цьому дина-міка їх зміни в часі виділяється протилежними тенденціями - постійним зростанням одноразових витрат на підвищення кваліфікації, числа кількості підвищення кваліфікації при одночасному зменшенні частки однакових видів витрат на відтворення робочої сили (на 1 рік трудової діяльності), зважаючи на збільшення загального періоду працездатності як наслідку збільшення тривалості життя. 3 іншого боку, за цих умов у результаті зменшення працез-датності, тривалості робочого часу, збільшення енергетичних витрат організму, погіршення можливостей для відновлення життєвих сил під час відпочинку падає продуктивність праці, скорочується об'єм і знижується якість продукції, що виробляється, зростають витрати на відновлення і профілактичне забезпечення нормального здоров'я тих, хто працює, їх медичного обслуговування в цілому [6].

\section{3. Літературний огляд}

В останні 30 років у світі активно розробляються підходи до вирішення проблем хронізації та інвалідності працюючого населення. За даними ВОO3, хронічно хворі складають 70, а інваліди - 10 відсотків усього населення земної кулі [7]. Значущість проблеми інвалідності населення працездатного віку багатофакторна. 3 одного боку, вона викликає істотний економічний збиток за умов, що темпи зростання первинного виходу на інвалідність випереджають смертність; регіоналізації інвалідності 3 концентрацією високих рівнів на економічно несприят- 
ливих територіях. 3 іншого боку, особи, що мають інвалідність, є активними користувачами медичної допомоги, складаючи істотний контингент пацієнтів амбулаторно-поліклінічних установ і стаціонарів [5, 8].

Встановлено, що середній вік виходу на інвалідність дорівнював 44,4 $\pm 13,7$ роки як серед чоловіків, так і жінок. Тобто первинна інвалідність $€$ проблемою молодого та працездатного віку за 10-ма класами хвороб, при яких їхня питома вага перевищила $80,0 \%$ [5].

\section{4. Мета дослідження, матеріали і методи}

Мета даного дослідження - розрахувати економічний ефект від попередження нещасних випадків на виробництві.

Методика визначення економічної ефективності грунтувалась на обрахунку опосередкованого економічного ефекту (ЕE), який визначався величиною попередженого економічного збитку через зменшенням прямих і непрямих витрат релевантних для системи охорони здоров'я, споживача медичних послуг та суспільства в цілому.

Розрахунок економічного ефекту потребував визначення оціночного критерію, яким у дослідженні став один випадок виробничої травми на промисловому підприємстві. Підбір показника здійснювався $з$ урахуванням того, що він мав кількісну міру вираження, мав пряме відношення до проведеної оцінки, досить чутливий до виявлення будь-яких змін, загальновизнаний i не викликав розбіжностей чи непорозумінь у тлумаченні, забезпечував можливість зіставлення результатів аналогічних досліджень.

Науковою базою дослідження вибрано чотири заклади охорони здоров'я - станція швидкої медичної допомоги (перша медична допомога), центр первинної медико-санітарної допомоги (амбулаторнополіклінічний етап лікування та диспансерного спостереження - I рівень), лікувально-профілак-тичний заклад (стаціонарний етап - II рівень) і НДІ реабілітації інвалідів Вінницького національного медичного університету імені М. І. Пирогова (реабілітаційний етап - III рівень). Джерелами інформації стали медична карта амбулаторного (ф. № 025/о) та стаціонарного (ф. № 003/o) хворого, офіційні дані Фонду соціального страхування від нещасних випадків на виробництві та професійних захворювань України й Державної служби статистики України.

Визначення ЕЕ одного випадку виробничої травми проводилось методом клініко-економічного аналізу «Загальна вартість лікування» [3], що дав можливість вирахувавши витрати на один випадок, екстраполювати їх на всю популяцію, при цьому забезпечуючи обчислення повної вартості захворювання на різних етапах надання медичної допомоги 3 виділенням елементів, які наносять найбільший збиток країні та обгрунтуванням прийняття управлінських рішень у системі охорони здоров'я щодо шляхів зниження обчислюваних і не обчислюваних збитків та витрат.

Показник загальної вартості лікування (COI) розраховувався за формулою:

$$
\mathrm{COI}=\mathrm{DC}+\mathrm{IC} \text {, }
$$

де COI - загальна вартість лікування; DC - прямі витрати; IC - непрямі витрати.

Обчислення COI на різних етапах надання медичної допомоги (амбулаторному - 1; стаціонарному - 2; реабілітаційному - 3) здійснювалось за формулою:

$$
\mathrm{COI}=\left(\mathrm{DC}_{1}+\mathrm{IC}_{1}\right)+\left(\mathrm{DC}_{2}+\mathrm{IC}_{2}\right)+\left(\mathrm{DC}_{3}+\mathrm{IC}_{3}\right),
$$

де $\mathrm{DC}_{1}, \mathrm{DC}_{2}, \mathrm{DC}_{3}$ - прямі витрати відповідно в амбулаторному, стаціонарному і реабілітаційному періодах; $\mathrm{IC}_{1}, \mathrm{IC}_{2}, \mathrm{IC}_{3}$ - непрямі витрати відповідно в амбулаторному, стаціонарному і реабілітаційному періодах.

Прямі витрати розподілялись на медичні й немедичні, перші 3 яких включали витрати на діагностичні дослідження, вартість медичних процедур та лікарських засобів, вартість ліжко-дня в стаціонарі й професійних медичних послуг (заробітна плата медичних працівників, оплата консультацій спеціалістів тощо).

Прямі немедичні витрати передбачали обчислення витрат, які відшкодовувались за рахунок самого хворого, членів його сім'ї, спонсорів (вартість лікарських засобів, виробів медичного призначення, витрати на харчування, медичну допомогу тощо).

Непрямі витрати пов'язані з непрацездатністю хворого у момент лікування, що призвело до недоотримання хворим заробітної плати (лише 80 \%), прибутку підприємством та суспільством у цілому (виплати по лікарняних листках за 172 дні хвороби, ВВП, надходження податків і т.д.), необхідністю соціального забезпечення, втрати від інвалідності працездатної особи.

Методи дослідження: програмно-иілььового планування - розробка програми; вибір і застосування комплексу адекватних методів дослідження; планування дослідження із забезпеченням етапності й послідовності виконання; моделювання - розробка моделей розрахунку економічного ефекту від попередження 1-го випадку виробничої травми та 1-го випадку інвалідності внаслідок виробничої травми на рік; економічний - визначення економічного ефекту від попередження 1-го випадку виробничої травми та 1-го випадку інвалідності внаслідок виробничої травми на рік.

\section{5. Апробація результатів дослідження}

Економія прямих витрат (медичних і немедичних) включала витрати на швидку медичну допомогу (A), стаціонарний (B), амбулаторний (C), реабілітаційний (D) етапи надання медичної допомоги та загальні витрати на фармакотерапію (Е) за весь період непрацездатності хворого.

Витрати на одного хворого в день швидкої медичної допомоги (А) склали 213 грн. 00 коп., що передбачало надання першої невідкладної медичної допомоги й доставку постраждалого до лікувальнопрофілактичного закладу.

Стаціонарний етап (В) розподілено на два 
періоди: перебування хворого в реанімаційному відділенні після проведеного оперативного втручання (чотири ліжко-дня; вартість одного ліжко-дня 1239 грн. 59 коп.) та продовження лікування в хірургічному відділенні (25 ліжко-днів; вартість одного ліжко-дня - 190 грн. 49 коп.), що в сумі склало 9720 грн. 61 коп. без урахування витрат на фармакотерапію. При цьому, вартість додаткового дієтичного харчування становила 520 грн. 00 коп., тобто загальна вартість стаціонарного етапу надання медичної допомоги дорівнювала 10240 грн. 61 коп.

Розрахунок вартості амбулаторного етапу лікування (C) одного випадку виробничої травми здійснено з урахуванням кількості годин роботи з одним хворим на місяць (i=12 годин) у центрі первинної медикосанітарної допомоги (ЦПМСД), кількості робочих годин сімейного лікаря на місяць (ii=162 години), середньомісячної зарплати сімейного лікаря на місяць у 2013 році (iii=3 291 грн. 00 коп.), середньої кількості днів спостереження за хворим у ЦПМСД (iv=49 днів), середньої кількості днів у місяці (v=30 днів), що у підрахунку за формулою склало 375 грн. 50 коп.:

$$
\begin{gathered}
\mathrm{C}=\mathrm{iii} *(\mathrm{i} / \mathrm{ii}) *(\mathrm{iv} / \mathrm{v})=3291,00 \text { грн. } *(12 \text { год./162 год. })^{*} \\
*(49 \text { днів/30 днів })=375,50 \text { грн. }
\end{gathered}
$$

Реабілітаційний етап (D) надання медичної допомоги включав прямі медичні витрати на одного хворого в день у реабілітаційному відділенні (i=261,25 грн.; ii=21 день) та вартість бюджетної путівки в санаторій «Хмільник» за 30 \% вартості (прямі немедичні витрати - iii=2 484,00 грн.):

$\mathrm{D}=\mathrm{i} * \mathrm{ii}+\mathrm{iii}=261,25$ грн. $* 21$ день $+2484,00$ грн $=7970,25$ грн.

Усі етапи надання медичної допомоги хворому супроводжувались витратами на фармакотерапію (Е), загальна вартість яких визначена в сумі 7 112,15 грн.

Ураховуючи високі витрати на фармакотерапію, дослідниками проведено АВС-аналіз для визначення найбільш вартісних лікарських засобів, зазначених у листках призначень медичної карти стаціонарного (ф. № 003/о) та медичної карти амбулаторного хворого (ф. № 025/о) постраждалого внаслідок виробничої травми (табл. 1).

Розподіл призначених лікарських засобів (торгових назв (ТН)) за АВС-аналізом

\begin{tabular}{|c|c|c|c|c|}
\hline Група & Кількість ТН & \% від асортименту & \% від продажу & Сума, грн. \\
\hline А & 17 & 37,0 & 78,6 & 5588,64 \\
\hline В & 13 & 28,2 & 16,4 & 1163,77 \\
\hline С & 16 & 34,8 & 5,0 & 359,74 \\
\hline Всього & 46 & 100,0 & 100,0 & 7112,15 \\
\hline
\end{tabular}

3'ясовано, що із загальної номенклатури ліків (46 торгових назв), сімнадцять (37,0\% від асортименту Л3) віднесено до групи А, на які витрачено $78,6 \%$ коштів від загальної суми придбаних 46 досліджуваних лікарських засобів. У групу В увійшло тринадцять (28,2 \% від асортименту Л3) торгових назв, тоді як до групи С - шістнадцять ТН (34,8 \% від асортименту Л3), на які витрачено 16,4 \% та 5,0 \% коштів від загальної суми призначеної фармакотерапії відповідно.

Проведений АВС-аналіз дозволив визначити лікарські засоби, які супроводжувались найбільшими витратами на їх придбання (група А), оскільки препарати цієї групи були або дуже дороговартісними (плазма - 744,63 грн., фраксипарин - 526,04 грн., альбумін - 2 103,13 грн., гордокс - 1 469,33 грн., еритроцитарна маса - 557,36 грн.), або мали велику кількість призначень (хлорофіліпт - № 25, натрію хлорид - № 31, спізеф - № 12, декасан - № 10), розрахунок яких був важливим при плануванні прямих немедичних витрат, тобто хворого або його родини, відповідно до випадку захворювання та його тривалості.

Результати формального VEN-аналізу довели, що переважну частку призначених лікарських засобів склали препарати групи «vital» (V), тобто життєво необхідні й наявні в Державному формулярі лікарських засобів V-го випуску (44 з $46 \mathrm{TH}$ ), вказуючи, таким чином, на раціонально проведену терапію на всіх етапах надання медичної допомоги.
За проведеними розрахунками, економія прямих витрат становила 25 911,51 грн.:

$\mathrm{E} \Pi \mathrm{B}=\mathrm{A}+\mathrm{B}+\mathrm{C}+\mathrm{D}+\mathrm{E}=213$ грн.+10 240,61 грн.+ $+375,50$ грн.+7 970,25грн.+7 112,15 грн. $=25$ 911,51грн.

Економія непрямих витрат (ЕНВ) включала вирахування недоданого валового внутрішнього продукту (F) за дні хвороби; оплату тимчасової непрацездатності (G) й витрати Фонду соціального страхування тимчасової непрацездатності від нещасних випадків на один курс санаторно-курортного (відновного) лікування (К).

При розрахунку недоданого ВВП на одного працюючого (F) використано дані номінального ВВП за 2013 рік (i=1 454931 млн. грн.), кількість зайнятого населення на кінець 2013 року (ii=20404,1 тис. осіб), кількість днів у році (iii=365 днів), кількість днів хвороби постраждалого від нещасного випадку (iv=172 дні), що становило:

$\mathrm{F}=\mathrm{BBП} /$ Пр. ${ }^{*}(д н і$ хвороби/днів у році)= $=\mathrm{i} / \mathrm{ii} *(\mathrm{iv} / \mathrm{iii})=1454931$ млн. грн./20 404,1 тис. осіб* *(172 дн./365 дн.) $=33513$ грн. 74 коп.

Оплата тимчасової непрацездатності (G) за весь період лікування включала середню заробітну плату у промисловій галузі Вінницького регіону за 2013 рік (i=2 787,00грн.), кількість днів захворювання (ii=172 дні), середню кількість днів 
у місяці (iіi - 30 днів), що в підрахунку склало 15 978,08 грн.:

$\mathrm{G}=\mathrm{i} / \mathrm{iii} * \mathrm{ii}=2787,00$ грн../30 днів*172 дні=15978,08 грн.

Витрати Фонду соціального страхування тимчасової непрацездатності від нещасних випадків на один курс (24 дні) санаторно-курортного (відновного) лікування (К) в санаторії «Хмільник» становило 5 796,00 грн.

Таким чином, економія непрямих витрат, вирахувана за формулою, склала 51 976,54 грн.:

$\mathrm{EHB}=\mathrm{F}+\mathrm{G}+\mathrm{K}=$

$=33$ 513,74 грн. +15 978,08 грн. +5 796,00 грн. $=51976,54$ грн.
При цьому, сумарний економічний ефект від попередження одного випадку виробничої травми склав 77 888,05 грн.:

$$
\mathrm{EE}=\mathrm{E} \Pi \mathrm{B}+\mathrm{EHB}=
$$

$=25911,51$ грн.+51 976,54 грн. $=77888,05$ грн.

За умови розрахунку ЕЕ для популяції постраждалих від нещасних випадків на виробництві за 2013 рік по Україні (9221 особа), цей показник дорівнював 71820521,00 грн. або \$ 8977565,1 (9221 особа*77 888,05 грн.).

Наступним етапом у розрахунку ЕЕ стало вирахування економії прямих і непрямих витрат щодо одного випадку інвалідності внаслідок виробничої травми на рік (рис. 1).

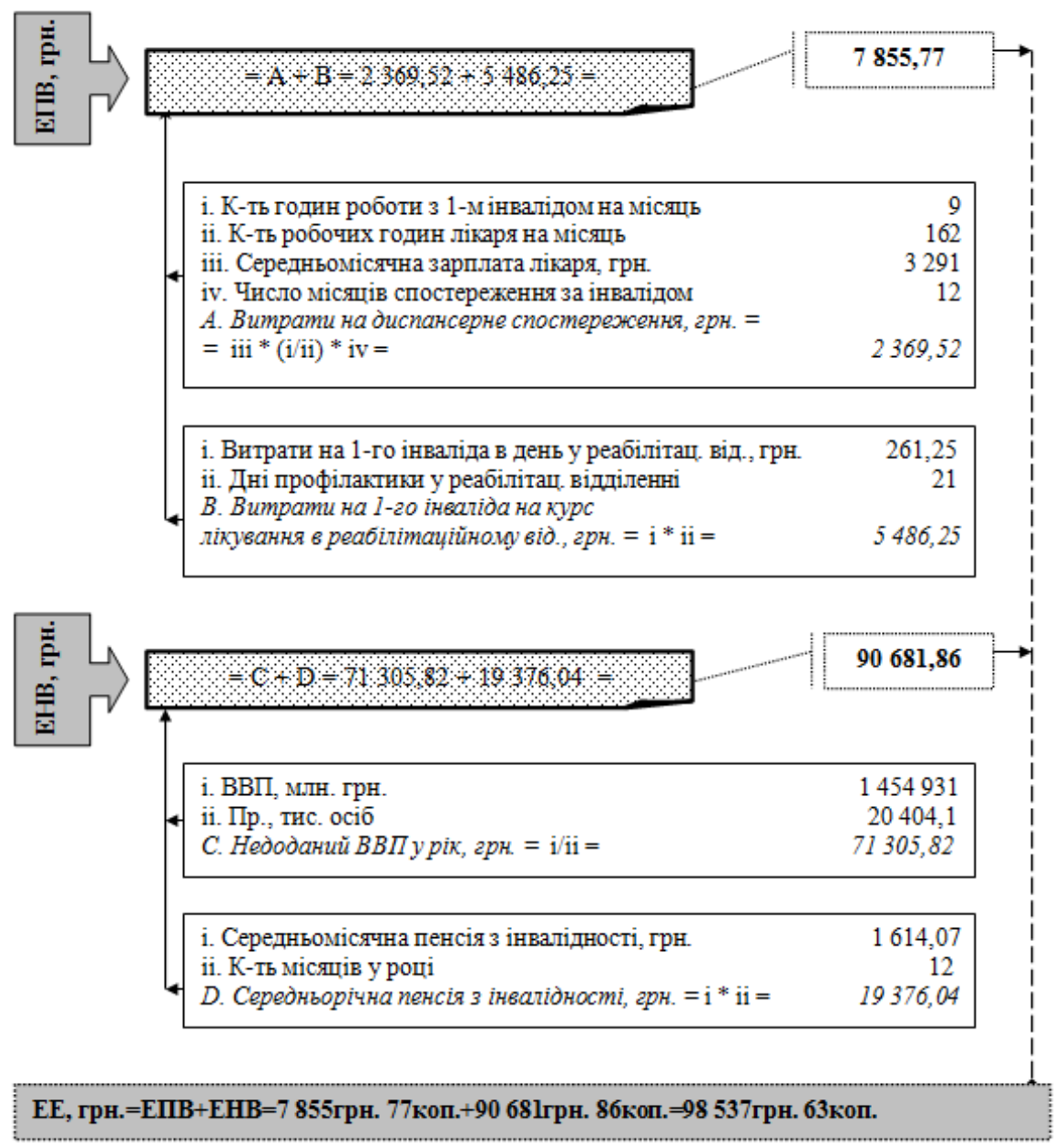

Рис. 1. Графологічна модель розрахунку ЕЕ від попередження одного випадку інвалідності внаслідок виробничої травми на рік

Економія прямих витрат (медичних і немедичних) включала витрати на диспансерне спостереження в амбулаторно-поліклінічному закладі (А) та курс лікування одного інваліда в реабілітаційному відділенні (В).

Розрахунок вартості диспансерного спостереження (А) одного випадку інвалідності виробничої травми здійснено з урахуванням кількості годин роботи 3 одним інвалідом на місяць (i=9 годин), кількості робочих годин лікаря на місяць (ii=162 години), середньомісячної зарплати лікаря на місяць у 2013 році (iii=3 291,00 грн.), числа місяців спостереження за інвалідом (iv=12 міс.), що у підрахунку за формулою склало 2 369,52 грн.:

$$
\mathrm{A}=\mathrm{iii}^{*}(\mathrm{i} / \mathrm{ii}) * \mathrm{iv}=
$$

$$
=3291 \text { грн. }{ }^{*}(9 \text { год./162 год.)*12 міс. }=2 \text { 369,52 грн. }
$$

Лікування в реабілітаційному відділенні (В) включало прямі медичні витрати на одного інваліда в 
день (i=261,25 грн.) при загальній кількості днів перебування (ii=21 день):

$\mathrm{B}=\mathrm{i} * \mathrm{ii}=261,25$ грн. $* 21$ день $=5$ 486,25 грн.

За проведеними розрахунками, економія прямих витрат склала 7 855,77 грн.:

$\mathrm{E} \mathrm{\Pi}=\mathrm{A}+\mathrm{B}=2$ 369,52 грн. +5 486,25 грн.=7 855,77 грн.

Економія непрямих витрат (ЕНВ) включала вирахування недоданого валового внутрішнього продукту у рік (C) та витрати на пенсію з інвалідності (D).

При розрахунку недоданого ВВП на одного інваліда (С) використано дані номінального ВВП за 2013 рік (i=1 454931 млн. грн.) та кількість зайнятого населення на кінець 2013 року (ii=20 404,1 тис. осіб), що становило:

$$
\begin{aligned}
& \text { С=ВВП/Пр.=i/ii= } \\
& =1454931 \text { млн. грн./20 404,1 тис. осіб=71 305,82 грн. }
\end{aligned}
$$

Видатки держави на пенсійне забезпечення (D) одного інваліда в місяць за 2013 рік становили i=1 614,07 грн., кількість місяців (ii=12 міс.), що в підрахунку за рік склало 19 376,04 грн:

$\mathrm{D}=\mathrm{i} * \mathrm{ii}=1$ 614,07 грн. ${ }^{*} 12$ міс. $=19$ 376,04 грн.

Таким чином, економія непрямих витрат, вирахувана за формулою, склала 90 681,86 грн.:

$\mathrm{EHB}=\mathrm{C}+\mathrm{D}=71305,82$ грн. $+19376,04$ грн. $=90681,86$ грн.

При цьому, сумарний економічний ефект від попередження одного випадку інвалідності внаслідок виробничої травми склав 98 537,63 грн.:

\section{$\mathrm{EE}=\mathrm{E} \Pi \mathrm{B}+\mathrm{EHB}=$}

$=7$ 855,77 грн.+90 681,86 грн.98 537,63 грн.

\section{6. Висновки}

1. Визначено, що найбільш економічно затратними етапами надання медичної допомоги при тимчасовій непрацездатності від виробничої травми були стаціонарний $\quad(10240,61$ грн.), реабілітаційний (7 970,25 грн.) та витрати на фармакотерапію (7 112,15 грн.), а серед непрямих витрат - недоданий ВВП на 1-го працюючого (33 513,74 грн.) й оплата тимчасової непрацездатності (15 978,08 грн.).

2. Доведено, що держава несе значні збитки при виникненні випадку інвалідизації працюючо-го - недоданий ВВП на одного інваліда (71 305,82 грн.) і видатки на пенсійне забезпечення (19 376,04 грн.) у рік.

3. Економічний ефект від попередження одного випадку виробничої травми склав 77888,05 грн., що на рівні популяції дорівнювало 71820 521,0 грн. або \$ 8977565,1 дол., а від попередження одного випадку інвалідності внаслідок виробничої травми 98537,63 грн.

4. Наведені розрахунки 3 визначенням найбільш фінансово затратних аспектів при настанні непрацездатності працюючого внаслідок виробничої травми, засвідчили необхідність перегляду та удосконалення національної політики щодо збереження та зміцнення здоров'я працюючої верстви населення за всіма компонентами його забезпечення під час здійснення ними трудової діяльності.

\section{Література}

1. Волобуєв, В. В. Економічна ефективність застосування диференційованого підходу в лікуванні непсихотичних психічних розладів у постраждалих внаслідок техногенних аварій та катастроф, заснованого на психоаналітично орієнтованій психотерапії [Текст] / В. В. Волобуєв // Вісник проблем біології і медицини. - 2014. - Вип. 3, Т. 1. - С. 51-55.

2. Колодяжна, О. І. Основні принципи і методологічні засади визначення економічних втрат від професійної захворюваності працюючого населення України [Текст] / О. І. Колодяжна, А. М. Нагорна, М. П. Соколова // Український журнал 3 проблем медицини праці. - 2012. № 1. - С. $81-85$.

3. Моісеєнко, Р. О. Єдина уніфікована методика розрахунку вартості медичних послуг, амбулаторно-поліклінічного та стаціонарного лікування [Текст] / Р. О. Моісеєнко, О. К. Толстанов, В. В. Залеська та ін. // Український медичний часопис. - 2012. - № 3. - С. 150-156.

4. Rice, D. P. Estimating the cost of illness [Text] / D. P. Rice // Health Economics Series. - Rockville, MD: U. S. Department of Health, Education and Welfare. - 1996. Vol. 6. - P. 6-947.

5. Кундієв, Ю. І. Професійне здоров'я в Україні. Епідеміологічний аналіз [Текст] / Ю. І. Кундієв, А. М. Нагорна. - К.: Авіцена, 2007. - 396 с.

6. Войтенко, В. П. Інвалідність в Україні: демографічні студії [Текст] : монографія / В. П. Войтенко, Н. М. Кошель. - К. : Науковий світ, 2008. - 197 с.

7. Social determinants of health: the solid facts [Electronic resource] / Available at: http:www.euro.who.int/_data/ assets/pdf_file

8. A review of methods used across Europe to estimate work - related accidents and illnesses among the self-employed [Text] / Eur. Agency for Safety and Health at Work, 2010. - 28 p.

\section{References}

1. Volobuyev, V. V. (2014). Ekonomichna efektyvnist' zastosuvannya dyferentsiyovanoho pidkhodu v likuvanni nepsykhotychnykh psykhichnykh rozladiv $u$ postrazhdalykh vnaslidok tekhnohennykh avariy ta katastrof, zasnovanoho na psykhoanalitychno oriyentovaniy psykhoterapiyi [Economic efficiency of application of the differentiated approach in treatment of nonpsychotic of psychical disorders in a victim as a result of industrial failures and catastrophes, based on the psychoanalytic oriented psychotherapy]. Visnyk problem biolohiyi i medytsyny, 3 (1), 51-55.

2. Kolodyazhna, O. I. (2012). Osnovni pryntsypy i metodolohichni zasady vyznachennya ekonomichnykh vtrat vid profesiynoyi zakhvoryuvanosti pratsyuyuchoho naselennya Ukrayiny [Basic principles and methodological principles of determination of economic losses are from professional morbidity of working population of Ukraine]. Ukrayins'kyy zhurnal z problem medytsyny pratsi, $1,81-85$.

3. Moiseyenko, R. O., Tolstanov, O. K., Zales'ka, V. V. et. al. (2012). Yedyna unifikovana metodyka rozrakhunku vartosti medychnykh posluh, ambulatorno-poliklinichnoho ta statsionarnoho likuvannya [Unique compatible method of calculation of cost of medical services, ambulatory policlinic and stationary treatment]. Ukr. med. Chasopys, 3, 150-156.

4. Rice, D. P. (1996). Estimating the cost of illness. Health Economics Series. - Rockville, MD: U. S. Department of Health, Education and Welfare, 6 (6), 947. 
5. Kundiyev, Yu. I., Nahorna, A. M. (2007). Profesiyne zdorov"ya v Ukrayini. Epidemiolohichnyy analiz [A professional health in Ukraine]. Kiev: Avitsena, 396.

6. Voytenko, V. P., Koshel', N. M. (2008). Invalidnist' v Ukrayini: demohrafichni studiyi [Disability in Ukraine]. Kiev: Naukovyy svit, 197.
7. Social determinants of health : the solid facts. Available at: http:www.euro.who.int/_data/assets/pdf_file

8. A review of methods used across Europe to estimate work - related accidents and illnesses among the self-employed (2010). Eur. Agency for Safety and Health at Work, 28.

Рекомендовано до публікаиії д-р мед. наук, проф. Очередько О. М. Дата надходження рукопису 25.12.2014

Крекотень Олена Миколаївна, кандидат медичних наук, доцент, кафедра соціальної медицини та організації охорони здоров'я, Вінницький національний медичний університет ім. М. I. Пирогова, вул. Пирогова, 56, м. Вінниця, Україна, 21018

E-mail: olena1977@mail.ru

Кабаненко Олена Геннадіївна, асистент, Вінницький національний медичний університет ім. М. І. Пирогова, вул. Пирогова, 56, м. Вінниця, Україна, 21018

E-mail: ya.fanwatch@yandex.ru

УДК 616.314,159.9.07

DOI: $10.15587 / 2313-8416.2015$.

\title{
ПСИХОЛОГИЧЕСКАЯ ОЦЕНКА ЭМОЦИОНАЛЬНОГО СОСТОЯНИЯ ЛИЧНОСТИ ПО ХАРАКТЕРИСТИКАМ ВЫРАЖЕНИЯ ГЛАЗ
}

\author{
(C) В. Н. Трезубов, Е. А. Булычева, Ю. В. Алпатьева, Д. С. Булычева
}

Практикуюшие стоматологи знают, как непросто найти контакт и взаимодействие с пациентами, страдаюшими заболеваниями жевательно-речевого аппарата. Наличие психохарактерологических нарушений у этих больных отмечают многие исследователи, одни из которых относят данные заболевания к разряду психосоматических, другие - к соматическим.

В связи с этим перед нами была поставлена цель: исследовать психохарактерологические особенности пациентов с патологией жевательно-речевого аппарата

Ключевые слова: психологический статус, выражение эмоций, глаза, эмоциональное состояние, жевательно-речевой аппарат

Clinical dentists know that it is very difficult to find a contact and to interact with patients suffering from diseases of the mastication and speech apparatus. Many researches pay attention to the psychiatric and character deviations of this type of patients. Some of them describe these deviations as psychosomatic, others describe them as physical.

Our goal was to explore the psychiatric and character features of the patients with the pathology of the mastication and speech apparatus and to reveal the specifics of the reduction of the disease symptoms under the influence of the adjuvant therapy. The research is based on the survey of 105 patients before and after the treatment using the "Scale of the emotional state based on the eye expression". The research revealed the changes in the emotional state of the patients with this pathology according to their eye expression. It means that the research created a new tool for the quantitative and qualitative evaluation of the eye expression as an indicator of the psycho-emotional state of a person - the tool that is additional for the basic psycho-diagnostic tests

Keywords: psychological status, expression of emotions, eyes, emotional state, mastication and speech apparatus

\section{1. Введение}

При первичном контакте с пациентом врачстоматолог внимательно оценивает его внешнюю экспрессию. Это порой происходит неосознанно, интуитивно, но всегда имеет важное значение для построения тактики поведения врача и формирования межличностного контакта с больным. Психические особенности пациентов весьма разнообразны и индивидуальны. Часть из них считываются врачом с выражения глаз, мимики и пантомимики. Для оценки глаз психологи и физиогномисты предлагают различные оценки личности по характеристикам глаз.

\section{2. Литературный обзор}

Оценкой индивидуально-психологических характеристик человека по выражению лица занимались многие ученые. Для анализа динамики выражения глаз психологами и физиогномистами предлагаются различные методики. Так, по мнению Майниной И. Н. (2011) [1], представление о личности незнакомого человека, основанное на изучении выражения его лица, включает не только «поверхностные» (черты личности), но и «глубинные» (экзистенциальные) характеристики, которые учитываются в процессе общения. 